YEARBOOK
of ANTITRUST
and REGULATORY
STUDIES
www.yars.wz.uw.edu.pl
Peer-reviewed scientific periodical, focusing on legal and economic issues of antitrust and regulation. Creative Commons Attribution-No Derivative Works 3.0 Poland License.

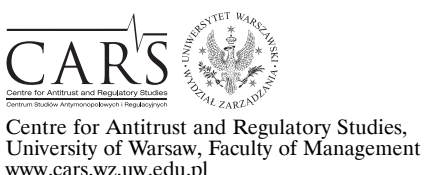

www.cars.wZ.uw.edu.pl

\title{
The Gazprom Case: Lessons of the Past For the Future
}

\author{
by
}

\author{
Dalia Višinskienė and Justina Nasutavičiené*
}

\section{CONTENTS}

I. Introduction

II. Modifications to concentrations under the EU competition law

III. Modifications to concentrations in the Republic of Lithuania

1. The aspect of commitments, conditions and obligations under the regulation of concentrations in the Republic of Lithuania

2. The aspect of concentration condition in the Gazprom case

IV. Final remarks

\section{Abstract}

Under the EU Merger Regulation, if the Commission has concerns that a merger may significantly affect competition in the European Union, the merging companies may propose modifications to the project that would guarantee continued competition on the market. The Commission may declare a concentration compatible with the common market following such a modification by the parties and attach to its decision conditions and obligations intended to ensure that the undertakings comply with the commitments. In other words, commitments have to be offered by the parties but the Commission may introduce conditions and obligations if they are required to ensure the enforceability of commitments.

Meanwhile the scope to propose merger modifications and the level of discretion of the competition authority are quite different under the Law on Competition of the Republic of Lithuania, adopted almost two decades ago. The goal of this paper is to reveal those differences and, with the help of the jurisprudence of the

* Dalia Višinskienė, The Supreme Administrative Court of Lithuania, d.visinskiene@lvat. lt; Justina Nasutavičienè, The Supreme Administrative Court of Lithuania, j.nasutaviciene@ lvat.lt. Article received: 30.05.2017, accepted: 21.08.2017. 
Supreme Administrative Court of Lithuania in the Gazprom case, to explain how this may impact future cases.

\section{Resumé}

En vertu du Règlement de l'UE sur les Concentrations, si la Commission craint qu'une fusion puisse affecter considérablement la concurrence dans l'Union Européenne, les sociétés qui fusionnent peuvent proposer des modifications qui garantiraient une concurrence continue sur le marché. La Commission peut déclarer une concentration compatible avec le marché commun à la suite d'une telle modification par les parties et joindre à sa décision les conditions et les obligations destinées à assurer le respect des engagements par les entreprises. En d'autres termes, les engagements doivent être proposés par les parties, mais la Commission peut introduire des conditions et des obligations si elles sont requises pour garantir le caractère exécutoire des engagements. Pendant ce temps la possibilité de proposer des modifications de fusion et le niveau de pouvoir discrétionnaire de l'autorité de la concurrence sont très différents en vertu de la Loi sur la Concurrence de la République de Lituanie, adoptée il y a près de vingt ans. Lobjectif de ce papier est de révéler ces différences et, avec l'aide de la jurisprudence de la Cour Administrative Suprême de Lituanie dans l'affaire Gazprom, d'expliquer comment cela pourrait affecter les affaires futures.

Key words: commitments; concentrations; EU competition law; Law on Competition of the Republic of Lithuania; Merger Regulation; the Gazprom case.

JEL: K21

\section{Introduction}

On May 1, 2004 Lithuania became a member of the European Union. From this date undertakings of the Republic of Lithuania, of other Member States or of the third countries, seeking to carry out a concentration in Lithuania, are subject to either the EU or national approval process, depending on whether the concentration is regarded as having a European or local dimension. Merger control was introduced in Lithuania in 1992, when the Law on Competition was adopted ${ }^{1}$. It was revised over time to keep track of European trends of merger regulation. In March 1999, a new revision of that law was

${ }^{1}$ Lietuvos Respublikos konkurencijos îstatymas (1992 m. rugsejjo 15 d. įstatymo redakcija Nr. I-2878) // TAR. Retrieved from: https://www.e-tar.lt/portal/lt/legalAct/TAR.1FACCFC52985 (5.04.2017). 
adopted $^{2}$. It defined the concepts of undertaking, concentration, acquisition of control of an undertaking, etc. and also detailed procedures to be followed by undertakings seeking to carry out a merger, established the rights and duties of the Competition Council regarding the examination of submissions and the adoption of decisions, either authorizing concentrations or imposing conditions and obligations. It also made provisions for sanctions for violating such conditions and obligations imposed by the Competition Council. The provisions of the law were modified at later stages, too, but the essential ones regarding the regulation of concentrations remain intact.

The practice of the administrative courts of Lithuania reveals that the most controversial issues in the enforcement of the provisions of the Law on Competition regulating concentrations arise in examining and assessing decisions of the Competition Council which impose sanctions on undertakings for the implementation of the concentration without notification or when the authorization of the Competition Council is not granted ${ }^{3}$.

At the end of 2016, the Supreme Administrative Court of Lithuania adopted the final procedural decision resolving a dispute over the resolution of the Competition Council to impose a sanction on Gazprom, a public jointstock company from the Russian Federation (hereinafter, OAO Gazprom) for the violation of a concentration condition imposed by the resolution of the Competition Council authorising Gazprom's concentration in 2004.

The circumstances of the case relating to the determination of the conditions and/or obligations of the concentration reveal differences of the regulation of this aspect of competition enforcement in Lithuanian and European Union law, which, in the opinion of the authors of this paper, are worth to be presented for legal professionals, academic society as well as undertakings participating in concentrations in the Republic of Lithuania.

2 Lietuvos Respublikos konkurencijos įstatymas (1999 m. kovo 23 d. ịstatymo redakcija Nr. VIII-1099) // TAR. Retrieved from: https://www.e-tar.lt/portal/lt/legalAct/TAR.B8B6AFC2BFF1 (5.04.2017); hereinafter, Lithuanian Competition Act 1999.

3 See for instance orders of the Supreme Administrative Court of Lithuania: case No A-520-634-13 of 25.04.2013, retrieved from: https://www.e-tar.lt/portal/lt/legalAct/ efe4ccf05cc911e68827af6e444cca37; case No A-1699-822/2015 of 17.12.2015, retrieved from: https://www.e-tar.lt/portal/lt/legalAct/a5891160ad8411e5b12fbb7dc920ee2c; case No A-899-858/2017 of 18.04.2017, retrieved from: https://www.e-tar.lt/portal/lt/legalAct/ d90062c02b6211e78397ae072f58c508. 


\section{Modifications to concentrations under the EU competition law}

As noted in the doctrine, while mergers can generate a range of pro-competitive effects, they may also negatively affect competition on a variety of markets (Layne-Farrar, Geradin and Petit, 2012, p. 498). Thus, the European Commission has an important role to inspect and, if necessary, prohibit concentrations linked to a lasting change in the structure of competition within the common market, thereby drawing on the powers conferred by Article 101 and 102 TFEU (Cook and Kerse, 2000).

According to the Council Regulation (EC) No 139/2004, the Commission has to appraise concentrations within the scope of the Merger Regulation with a view to establishing whether or not they are compatible with the common market. For that purpose, the Commission must assess, pursuant to Article 2(2) and (3), whether or not a concentration would significantly impede effective competition, in particular by creating or strengthening a dominant position in the common market or a substantial part of it ${ }^{5}$.

If the Commission has concerns that a merger may significantly affect competition, the merging companies may offer remedies ("commitments"), i.e. propose certain modifications to the project that would guarantee continued competition on the market ${ }^{6}$. It is important to stress that it is the responsibility of the parties to present commitments to address the Commission's concerns and thereby seek a conditional clearance of their merger. The Commission is "not in a position to impose unilaterally any conditions to an authorisation decision, but only on the basis of the parties' commitments" " If, however, the parties do not validly propose commitments viewed as adequate to eliminate competition concerns, the only option for the Commission is to adopt a prohibition decision ${ }^{8}$. Moreover, as it was concluded from the practice of this institution, the Commission has a fairly restrictive approach towards accepting commitments after the expiry of deadlines for offering them. In such cases it is also inclined to prohibit the concentration or require the parties

${ }^{4}$ Council Regulation (EC) No 139/2004 of 20.01.2004 on the control of concentrations between undertakings (OJ L 24, 29.01.2004, p. 1), hereinafter, the EU Merger Regulation.

5 Guidelines on the assessment of horizontal mergers under the Council Regulation on the control of concentrations between undertakings (OL C 31, 5.02.2004, p. 5), para. 1.

${ }^{6}$ European Commission, Merger control procedures, retrived from: http://ec. europa.eu/ competition/mergers/procedures_en.html (5.04.2017).

7 Commission notice on remedies acceptable under Council Regulation (EC) No 139/2004 and under Commission Regulation (EC) No 802/2004 (OJ C 267, 22.10.2008, p. 1) (hereinafter, Remedies Notice), para. 6.

8 Ibidem. 
to make a fresh notification of the proposed concentration to encompass the proposed commitments (Tosato and Bellodi, 2006, p. 315).

Modifications to concentrations are more commonly described as "remedies" since their object is to eliminate competition concerns identified by the Commission ${ }^{9}$. Remedies are conventionally classified as either structural or non-structural ${ }^{10}$. Structural remedies are explained as generally one-time remedies intended to maintain or restore the competitive structure of the market. They typically involve the sale of one or more businesses, physical assets or other rights to address concerns about competitive harm by strengthening an existing player, creating a new source of competition or a mix of both ${ }^{11}$. A structural remedy needs some monitoring and - where necessary - enforcement until a divestiture is completed but this concerns only a limited period of time (usually several months) (Maier-Rigaud and Frank, 2016). By contrast to structural remedies, non-structural ones, often referred to as "conduct" or "behavioural" remedies, are ongoing remedies that are designed to modify or constrain the future conduct of merging firms ${ }^{12}$. They do not restructure firms or asset ownership but only permit integration subject to specific operating rules aimed to alter marketplace behaviour of the merging parties to prevent them from undermining competition ${ }^{13}$. Non-structural remedies are less common than structural ones in merger cases, but more common in collusion or abuse of dominance cases, and require ongoing or at least periodic monitoring. Therefore the main theoretical attraction of structural remedies is that they create the need to intervene only once: after the issue of excessive market power is resolved, the newly created competitive structure can be left to its own devices and does not require supervision which would be needed if a behavioural remedy was imposed instead (Niels, Jenkins and Kavanagh, 2011, p. 445, 446, 453, 454).

Nevertheless an effective package of remedies may contain a combination or "hybrid" of both structural and non-structural elements ${ }^{14}$. Hybrid measures are measures that do not affect the allocation of ownership rights but instead modify the structure of the market by, for instance, allowing the entry of a new player, mandating the merged entity to grant a technology licence to a potential competitor or to terminate exclusivity agreements, etc. (Layne-Farrar, Geradin and Petit, 2012, p. 534).

9 Remedies Notice, para.2.

10 ICN Merger Working Group, International Competition Network, Merger Remedies Guide 2016, retrieved from: http://www.internationalcompetitionnetwork.org/uploads/library/ doc1082.pdf (5.04.2017).

11 Ibidem.

12 ICN Merger Working Group, Merger Remedies Guide 2016.

13 Ibidem.

14 ICN Merger Working Group, Merger Remedies Guide 2016. 
The importance of remedies in the EU merger regulation is shown inter alia via the Commission's effort to provide guidance (Notice on Remedies) on the types and forms of remedial actions acceptable under the EU Merger Regulation, as well as the establishment of a specialised enforcement unit, which gives internal advice on the acceptability and implementation of remedies, in this way developing a consistent application of remedies in merger cases (Bael, 2001, p. 492). One aspect showing the significance of remedies is that they all may be considered more or less burdensome in terms of fundamental rights: while structural remedies may have a bearing on property rights if, for instance, a sale of assets is required, behavioural remedies bear upon the freedom to conduct business, including the freedom to contract (Hellstrom, Maier-Rigaud and Wenzel Bulst, 2009, p. 47).

Merger Regulation in Article 6(2) and 8(2) expressly provides that the Commission may decide to declare a concentration compatible with the common market following modification by the parties, both before and after the initiation of proceedings and to that end, the Commission may attach to its decision conditions and obligations intended to ensure that the undertakings concerned comply with the commitments they have entered into vis-à-vis the Commission with a view to rendering the concentration compatible with the common market ${ }^{15}$. So, whilst commitments have to be offered by the parties, it is for the Commission to introduce conditions and obligations if they are required to ensure the enforceability of commitments.

As it is emphasized, a distinction must be made between conditions and obligations ${ }^{16}$. From the practice of the Commission it has been concluded that the way in which this institution imposes conditions and obligations has generally been clear, transparent and consistent: the fulfilment of the measure that gives rise to a structural change of the market is considered a condition, whereas the implementing steps necessary to achieve this result are considered obligations (Hoeg, 2014).

But a more important aspect are the legal consequences of a violation of remedies imposed by the Commission. If the undertakings concerned commit a breach of an obligation attached to the decision, according to articles 6(3) or 8(6) of the Merger Regulation, the Commission may revoke the decision it took pursuant to Article $6(1)(a)^{17}$ or $(b)^{18}$. Besides, the Commission may

15 Remedies Notice, para. 1.

16 Remedies Notice, para. 19.

17 The provision states that „Where it concludes that the concentration notified does not fall within the scope of this Regulation, it shall record that finding by means of a decision".

18 The provision states that "Where it finds that the concentration notified, although falling within the scope of this Regulation, does not raise serious doubts as to its compatibility with 
impose fines for failing to comply with an obligation ${ }^{19}$ as well as periodic penalty payments in order to compel parties to comply ${ }^{20}$.

When a condition attached to an approval decision is being breached, the situation rendering the concentration compatible with the common market does not materialize and the concentration, as implemented, is therefore not authorized by the Commission ${ }^{21}$. In that case the Commission may take appropriate interim measures to restore or maintain conditions of effective competition $^{22}$. Moreover, if certain conditions set in Article 8.4(b) are met, the Commission may require the undertakings concerned to dissolve the concentration, in particular through the dissolution of the merger or the disposal of all the shares or assets acquired, so as to restore the situation prevailing prior to the implementation of the concentration. It may order any other appropriate measure to ensure that the undertakings concerned dissolve the concentration or take other restorative measures as required in its decision. Also, parties may be subject to fines ${ }^{23}$.

This regulation reveals that the violation of conditions and the violation of obligations attached to a Commission decision cause different legal consequences under the Merger Regulation. Therefore the Commission must be precise and clear identifying both when it sets remedies to ensure that the undertakings comply with the commitments they have proposed. This aspect is also important from the undertaking's point of view since it must be able to foresee the legal consequences of behaviour which might constitute a violation. Therefore the Commission usually concludes in its decision authorising a concentration that the finding of compatibility is conditional upon full compliance with the conditions and obligations of the commitments as set out in the annex, which forms an integral part of the decision. The annex specifies which provisions in the parties' commitments are considered conditions and which obligations (Hoeg, 2014). Regarding the question if the Commission can formally impose obligations which the parties have not proposed as commitments, it has been suggested that as far as the purpose of an obligation is to ensure that the conditions are fully implemented, it can be argued that it would be appropriate and proportionate and even beneficial to the parties if the Commission could impose certain additional obligations, as the alternative would mean having to dismiss the commitments proposal

the common market, it shall decide not to oppose it and shall declare that it is compatible with the common market".

19 Article 14.2(d) of the EU Merger Regulation.

20 Article 15.1 (c) of the EU Merger Regulation.

21 Recition 31 of the preamble of the EU Merger Regulation.

22 Article 8.5(b) of the EU Merger Regulation.

23 Article 14.2(d) of the EU Merger Regulation. 
altogether. Nevertheless, such changes should only relate to modalities of remedies and not the nature or scope of the assets to be divested, as such additions would clearly qualify as new commitments ${ }^{24}$.

To sum up, under the EU competition law, merging companies may propose certain modifications to the merger project that would guarantee continued competition on the market and it is for the Commission to assess whether the proposed remedies, once implemented, would eliminate the competition concerns identified. The Commission may decide to declare a concentration compatible with the common market following modification by the parties, attaching to its decision conditions and obligations. But the Commission cannot impose unilaterally any conditions which are not based on the parties' own commitments. Moreover a distinction must be made between conditions and obligations because a violation of one or the other determines completely different legal consequences.

The mechanism for modifying concentrations under the Law on Competition of the Republic of Lithuania shows significant differences with the model described above.

\section{Modifications to concentrations in the Republic of Lithuania}

Merger control in the Republic of Lithuania began in 1992, when the first Law on Competition was adopted. As part of the later effort to join the European Union, it was considered appropriate to regulate concentrations in the way they would be regulated by the Commission if they exceeded the threshold of the turnover (Banevičienè, 2005, p. 73). Therefore, in 1999 a revision of the Law on Competition was adopted and it was considered to be including all developments and trends in the regulation of concentrations in the (then) European Community.

The Supreme Administrative Court of Lithuania bearing in mind the necessity and importance of concentration regulation stated that the aim of such regulation inter alia is to preserve the market's structure, allowing effective competition in the market, because in certain cases merger may change the market's structure so as to reduce competition ${ }^{25}$. In a broader

24 Ibidem.

25 Order of the Supreme Administrative Court of Lithuania of 1.03.2012, A 502 $^{5668 / 2012}$, retrieved from: http://liteko.teismai.lt/viesasprendimupaieska/tekstas.aspx?id=1c3c81b0-5e094c8a-8da9-6bc619f6f921 (5.04.2017); order of the Supreme Administrative Court of Lithuania of 22.12.2016, eA-2330-520/2016, retrieved from: https://www.e-tar.lt/portal/lt/legalAct/62cc9e b0cde911e68d5e8b3a36d1fab2 (5.04.2017). 
sense undertakings are prohibited from performing any acts which restrict or may restrict competition, regardless of the character of their economic activity, except in cases where the Law on Competition or laws governing individual areas of economic activity provide for exemptions ${ }^{26}$. It is worth mentioning that the Law on Competition is also applied to activities of undertakings registered outside the territory of the Republic of Lithuania if the said activities restrict competition on the domestic market of the Republic of Lithuania ${ }^{27}$.

\section{The aspect of commitments, conditions and obligations under the regulation of concentrations in the Republic of Lithuania}

The Law on Competition No VIII-1099 defined concentration as: 1) a merger, when one or more undertakings which terminate their activity as independent undertakings are joined to the undertaking which continues its operations, or when a new undertaking is established from two or more undertakings which terminate their activity as independent undertakings; 2) acquisition of control, when the same natural person or natural persons already controlling one or more undertakings, or one or more undertakings, by agreement, jointly set up a new undertaking or gain control over another undertaking by acquiring an enterprise or part thereof, all or part of the assets of the undertaking, shares or other securities, voting rights, by contract or by any other means ${ }^{28}$.

An intended concentration must be notified to the Competition Council and its permission must be obtained where the combined aggregate income of the undertakings concerned in the business year preceding the concentration was more than 30 million litas ( 8.7 million euro) and the aggregate income of each of at least two undertakings concerned in the business year preceding the concentration was more than 5 million litas ${ }^{29}$. A notification of concentration must be submitted to the Competition Council no later than 7 days after the proposal to conclude a contract or purchase shares or assets, the order to

${ }^{26}$ Lietuvos Respublikos konkurencijos įstatymas (2017 m. vasario 1 d. įstatymo redakcija Nr. XIII-193) // TAR, retrieved from: https://www.e-tar.lt/portal/lt/legalAct/TAR.B8B6AFC2BFF1/ qqjSwVVuUG (5.04.2017) - Article 2(1).

27 Article 2(2) of the above Act. It should also be noted that economic activity means any type of manufacturing, commercial, financial or professional activities associated with the purchase or sale of goods, except for acquisitions by natural persons intended for personal and household needs (Article 3(1)). Restriction of competition is defined as any actions which constitute an obstacle to compete in a relevant market or may weaken, distort or otherwise have a negative effect on competition (Article 3(3)).

28 Article 3(14)(1)-(2) of the Lithuanian Competition Act 1999.

29 Article 10(1) of the Lithuanian Competition Act 1999. 
conclude a contract, conclusion of a contract, acquisition of property rights or the right to dispose of certain assets ${ }^{30}$.

Upon completing the examination of the notification of concentration, the Competition Council can adopt a resolution to authorize the concentration in accordance with the submitted notification ${ }^{31}$ or to refuse authorisation when the concentration would result in the creation or strengthening of a dominant position and this would substantially restrict competition on the relevant market $^{32}$.

Under the law, the Competition Council could also authorize a concentration subject to the conditions and obligations established by the Council for the concerned undertakings or controlling persons to prevent the creation or strengthening of a dominant position ${ }^{33}$. However, neither the Lithuanian Competition Act 1999 (Law on Competition No VIII-1099), nor any other legal act of the Republic of Lithuania gives undertakings the specific right and possibility to offer modification commitments.

Therefore judging from the letter of the law, the parties are able to submit only the notification of concentration to the Competition Council, without the ability to offer commitments to address any competition concerns raised by the merger as notified.

Unlike the Commission, which in the absence of valid commitments from the parties addressing the authority's competition concerns must adopt a prohibition decision, the Lithuanian Competition Council can therefore authorise a concentration subject to conditions and/or obligations established by itself. Moreover, without the parties' commitments as the basis for conditions and obligations for the merger, the Competition Council has the authority to unilaterally impose any remedy which in its opinion was necessary to prevent the creation or strengthening of a dominant position ${ }^{34}$. For instance, in one decision regarding a beer market concentration, the Competition Council obliged the notifying parties to sell one of the companies participating in the concentration to a third party while at the same time ordering them to maintain the company's separate identity until the sale was completed by a confidential deadline set by itself. Parties were also obliged to inform the Competition Council about all ongoing activities pertaining to the sale of the company,

30 Article 11(2) of the Lithuanian Competition Act 1999.

31 Article 14(1)(1) of the Lithuanian Competition Act 1999.

32 Article 14(1)(3) of the Lithuanian Competition Act 1999.

33 Article 14(1)(2) of the Lithuanian Competition Act 1999.

34 Amendment No XI-216 of the Lithuanian Competition Act, dated from 9.04.2009, widened the notion providing that the Competition Council could establish conditions and obligations also necessary to prevent a substantial restriction of competition in a relevant market. 
including naming potential buyers, describing the potential deal structure etc., with the aim of being able to assess and approve the disposal. The decision also obliged parties to seek permission of the Competition Council to perform any action they planned as implementation of the obligations and conditions set in the approval ${ }^{35}$. In other words, an exhaustive list of conditions and obligations was imposed by the Competition Council without any commitments being presented by the merging parties.

Another important difference from the EU merger control law is the aspect of legal consequences when merger conditions or obligations are being violated. As it was discussed in chapter II, a violation of conditions and a violation of obligations set by the Commission cause different legal consequences under the EU competition law. But the Lithuanian Competition Act 1999 simply stated that the Competition Council would have the right to amend or repeal its resolution on a concentration where the undertakings or controlling persons violated the conditions and obligations of the implementation ${ }^{36}$. It could also impose a fine for an infringement of concentration conditions or mandatory obligations it established ${ }^{37}$.

Hence, neither the Lithuanian Competition Act 1999, nor any other national legal act ${ }^{38}$ has differentiated this aspect of legal consequences of a violation of conditions or obligations. This implies that the Competition Council is not obliged to determine exactly what constituted a condition or an obligation in its decisions because any legal consequences were the same.

Accordingly, the analysis of the Competition Council practice shows that when only one or two remedies were imposed, they were usually regarded as conditions ${ }^{39}$ and contained a prohibition to reorganize the undertaking in a specific way, as well as an order to set prices and other conditions

35 Resolution No 123 of the Competition Council of the Republic of Lithuania, dated from 9.11.2000: „Regarding Carlsberg A/S notification on concentration acquiring the control of Kalnapilis AB, UAB Utenos alus, Jungtinis alaus centras“, retrieved from: http://kt.gov.lt/lt/ dokumentai/del-carlsberg-a-s-pranesimo-apie-koncentracija-isigyjant-ab-kalnapilis-uab-utenosalus-uab-jungtinis-alaus-centras-kontrole (5.04.2017).

36 Article 15(2) of the Lithuanian Competition Act 1999.

37 Article 41(1) of the Lithuanian Competition Act 1999.

38 For instance, The Rules concerning the setting of the amount of a fine imposed for the infringement of the Law on Competition of the Republic of Lithuania, approved by the resolution of the Government of the Republic of Lithuania, No. 1591, 6.12.2004 or subsequent Procedure for the fixing of the amount of fines imposed for infringements of the Lithuanian Law on Competition, approved by the by the resolution of the Government of the Republic of Lithuania, No 64, 18.01.2012.

39 See, for instance, resolutions of the Competition Council: No 21 of 28 February 2002, No 82 of 18.07.2002, No 1S-88 of 3.09.2003, No 1S-101 of 25.09.2003, No 1S-38 of 18.03.2004, No $1 \mathrm{~S}-119$ of 18.09 .2008 . 
for transactions between certain undertakings in the same way as similar transactions with other economic entities. But when a more extensive list of remedies was deemed necessary, the Competition Council usually stated that it decided to authorise a concentration according to the submitted notification with the following obligations and conditions (after what the list of all remedies was presented $)^{40}$.

Given such a broad discretion of the Competition Council, it is very important to stress the possibility for the undertakings to turn to the Competition Council for clarification of the imposed conditions and obligations if they seem to be too abstract or vague or to challenge them in court during the term set for appeals. A Resolution of the Competition Council authorising a concentration subject to certain conditions and obligations has been considered an administrative act which causes legal consequences for the undertakings concerned. Therefore those undertakings have the right to appeal to administrative courts and challenge the substance and legitimacy of such administrative acts within a certain period of time ${ }^{41}$, after which the resolution would become effective. In this respect, it should be stressed that when the Competition Council adopts a resolution declaring a violation of the conditions and obligations attached to an earlier authorization of concentration, it is too late to raise questions of legitimacy or clarity of such conditions or obligations. Such questions do not concern the object of the contested infringement resolution but the object of an older resolution authorizing the concentration, for which the term of appeal had already expired.

To sum up, the Law on Competition No VIII-1099 is silent on the ability of undertakings to propose commitments while giving the Competition Council discretion to unilaterally impose conditions and obligations it sees necessary to prevent the creation or strengthening of a dominant position, without even separating those remedies according to legal consequences of their violation. On the other hand, despite this broad discretion of the Competition Council, there was always a way for the undertaking participating in a concentration to seek clarification of the adopted resolution or to challenge its substance and legitimacy in court.

40 See, for instance, Resolutions of the Competition Council: No 123 of 9.11.2000, No 1S-107 of 2.10.2003, No 1S-140 of 11.12.2003, No 1S-80 and of 27.05.2004, No No 1S-121 and 1S-122 of 27.10.2005, No 1S-190 of 29.12.2007, No 1S-118 of 18.09.2008, etc.

41 Article 38(2) of the Lithuanian Competition Act 1999 established a 20 day period after the receipt of the resolution of the Competition Council or the date of publication of operative part of the resolution in the "Official Gazette". 


\section{The concentration condition in the Gazprom case}

In 2002, an international tender was announced for the selection of a gas supplier and acquirer of a 34\% stake in Joint-Stock Company Lietuvos dujos. It was won by OAO Gazprom - an undertaking established in the Russian Federation. In 2003 OAO Gazprom initialled the share purchase and signed a sales agreement on January 23, 2004. On the same day, OAO Gazprom submitted a notification of the concentration to the Competition Councill ${ }^{42}$.

On March 18, 2004 the Competition Council adopted the resolution No 1S-38 "Regarding the authorisation of OAO Gazprom to acquire 34\% of Joint-Stock Company Lietuvos dujos and jointly with SE Valstybès turto fondas, Ruhrgas Energie Beteiligungs AG and E.ON Energie AG acquire control over Joint-Stock Company Lietuvos dujos" (hereinafter, the Resolution No 1S-38). In considering the notification, the Competition Council took into account inter alia the following facts: i) Lietuvos dujos was holing a dominant position in the relevant markets of natural gas transmission and distribution, ii) the networks of Lietuvos dujos were not connected to the gas networks and the gas supply system of other EU member states and iii) that OAO Gazprom was the sole supplier of natural gas to Lithuania, with no other alternative suppliers present because other gas extraction companies in the Russian Federation had to use OAO Gazprom's network for delivery.

Therefore the Competition Council decided to authorise the concentration with the condition that the participating undertakings would not create obstacles for other gas supply companies which contracted with commercial buyers in Lithuania, for consumers wishing to enter natural gas purchase contracts with other gas production or supply companies and for other undertakings extracting natural gas wishing to supply buyers in Lithuania. Hence, it was a future-oriented, behavioural condition requiring certain behaviour of the undertakings participating in the concentration for an unspecified period of time (effectively meaning at least 2015, the final year of an earlier gas supply contract between Lietuvos dujos and OAO Gazprom ${ }^{43}$ ).

42 Resolution No 1S-38 of the Competition Council of the Republic of Lithuania, dated from 18.03.2004: "Regarding the authorisation of OAO Gazprom to acquire a $34 \%$ of AB Lietuvos dujos and jointly with SE Valstybès turto fondas, Ruhrgas Energie Beteiligungs AG and E.ON Energie AG acquire control over AB Lietuvos dujos", retrieved from: http://kt.gov. lt/lt/dokumentai/del-leidimo-oao-gazprom-vykdyti-koncentracija-isigyjant-34-ab-lietuvos-dujosakciju-paketa-ir-igyjant-kartu-su-vi-valstybes-turto-fondas-ruhrgas-energie-beteiligungs-ag-ir-eon-energie-ag-bendra-ab-lietuvos-dujos-kontrole (5.04.2017).

43 This deadline was enshrined in the Resolution of the Government of the Republic of Lithuania No 22 "On Assenting to a Draft Agreement on Sale and Purchase of 34 Percent of the Shares (Which Belong to the State by Right of Ownership) of the Joint-Stock Company 'Lietuvos Dujos', Annexes to This Agreement, as Well as to a Draft Agreement of Shareholders" 
Ten years later, the Competition Council adopted the resolution No 2S-3/2014 declaring that OAO Gazprom, by refusing to negotiate with Joint-Stock Company Lietuvos energijos gamyba over a gas swap agreement for the period 2013-2015, created an obstacle for this undertaking to conclude a natural gas purchase contract for its own needs with a gas supply company and in this way violated provisions of the Resolution No $1 \mathrm{~S}-38^{44}$. The Competition Council found that OAO Gazprom had engaged in such gas swap agreements for the supply of natural gas to the United States and therefore this undertaking was familiar with agreements of such nature.

In the subsequent appeal case before the Supreme Administrative Court of Lithuania, OAO Gazprom argued that: i) the concentration condition was interpreted in an expanded way by the Competition Council; ii) a representative of the Competition Council had acknowledged that the concentration condition, i.e. the prohibition "not to create obstacles" was not really a condition but an obligation to take all necessary measures to ensure that Lithuanian consumers can purchase gas from other suppliers; iii) it was incorrect to assume that the phrase "not to create obstacles" was synonymous with the phrase "take all necessary measures" so that "Lithuanian consumers will be able to buy natural gas from other natural gas suppliers than the applicant". The analysis of the wording of some resolutions of the Competition Council, according to OAO Gazprom, indicated that the concentration condition was a prohibition of certain acts, but in no way was an obligation to take active action in favour of competitors. Finally, the abstractness of the concentration condition testified that this was a "condition" or "prohibition", but not an "obligation" to take active and very concrete actions ${ }^{45}$.

Since OAO Gazprom in its appeal relied also on the provisions of EU competition law and the practice of the European Commission, the Supreme Administrative Court of Lithuania (hereinafter, the Court) reviewed not only the discretion of the Competition Council under national law, but also the regulation of modifications to concentrations under the EU law. After assessing the essential regulatory differences relevant to the issue under

of 9.01.2004, para. 3, retrieved from: https://www.e-tar.lt/portal/lt/legalAct/TAR.92E9739F47FE (5.04.2017).

44 Resolution No 2S-3/2014 of the Competition Council of the Republic of Lithuania, dated from 10.06.2014, "Regarding the compliance of the actions of OAO Gazprom with the 18 March 2004 Resolution No 1S-38 of the Competition Council of the Republic of Lithuania”, retrieved from: http://kt.gov.lt/lt/dokumentai/del-em-oao-gazprom-em-veiksmu-atitiktieslietuvos-respublikos-konkurencijos-tarybos-2004-m-kovo-18-d-nutarimo-nr-1s-38-nuostatoms (5.04.2017).

45 Order of the Supreme Administrative Court of Lithuania of 22.12.2016, paras. 72, 77, 78, 86; hereinafter, Order of the Court. 
consideration (as discussed in previous chapters of this paper), the Court rejected the arguments of OAO Gazprom.

First, the Court emphasised that the fact that a violation of a condition and a violation of an obligation cause different legal consequences under the EU law did not apply to the assessment of concentrations at national level because the Law on Competition No VIII-1099 did not differentiate legal consequences in this respect. That is to say that conditions and obligations (qualifying them together and assessing them in the national context) are being understood as determination of certain forms of behaviour, which would help ensure that the concentration would not result in creation or strengthening of a dominant position. ${ }^{46}$. According to the Court, in each case it is being looked into the question whether a remedy and, more specifically which type of remedy, is suitable to solve the identified competition concerns ${ }^{47}$. Assessing the concentration condition in the context of Article 14(1) paragraph 2 of the Law on Competition No VIII-1099 (which established the discretion of the Competition Council to adopt a resolution to authorise a concentration subject to conditions and obligations), the Court concluded that the condition under consideration was imposed in order to prevent negative consequences that could arise because of the concentration, taking into account the dominant position of Lietuvos dujos and, most importantly, the dominant position of OAO Gazprom, which at the time was the only supplier of gas to Lithuania. It also controlled trunk pipelines by which gas could enter Lithuania. Therefore in the Court's opinion, by restricting the ability of the undertakings participating in the concentration to cause negative consequences for competition, the Competition Council was preventing those entities from taking advantage of their dominant position or strengthening it. The Court concluded that by imposing such a condition, the Competition Council sought to counterbalance the ability of the concentrating parties with a dominant position to exercise decisive influence on natural gas consumers in Lithuania, and as such, this aim was considered by the Court as intended to prevent a strengthening of a dominant position ${ }^{48}$.

Secondly, the Court regarded the concentration condition as a broad one but pointed out that the law did not restrict the discretion of the Competition Council to choose conditions and obligations which it would judge appropriate to achieve specified purposes (to prevent the creation or strengthening of a dominant position $)^{49}$. It was acknowledged that when determining the modification to the concentration, the Competition Council did not separately

\footnotetext{
46 Order of the Court, para. 217.

47 Order of the Court, para. 218.

48 Order of the Court, para. 220.

49 Order of the Court, para. 224.
} 
define conditions and obligations. However, in the Court's view, it had no legal significance in resolving the dispute over the validity of the resolution No 2S-3/2014 (by which a violation of the concentration condition was declared). The Court emphasised that if OAO Gazprom disagreed with the imposed condition and considered that it did not comply with the provisions of the Law on Competition, or did not understand it, it had the opportunity to appeal the resolution No 1S-38 to demand that this condition be terminated and/or explained by the Competition Council. Rejecting the arguments of OAO Gazprom that the concentration decision was abstract and uncertain, the Court noted that the said undertaking carried out the concentration and did not apply to the Competition Council for clarification of this condition. The complaint regarding uncertainty of the condition was raised only when the Competition Council declared a violation of this condition ${ }^{50}$.

Thirdly, the Court ruled that the law allowed the Competition Council to determine necessary conditions and obligations according to its own view. In this respect, the Competition Council had the competence to choose not necessarily only one kind of competition remedies. Consequently, the Competition Council was not obliged to choose between the imposition of conditions or imposition of obligations. On the other hand, the Competition Council was not obliged to impose conditions necessarily together with obligations ${ }^{51}$. Thus as far as the Law on Competition No VIII-1099 did not differentiate between legal consequences of a violation of a condition and a violation of an obligation, the Court repeated that there was no essential difference whether the requirement established by the Competition Council "not to create obstacles" for the development of a competitive gas market should be considered a condition or an obligation ${ }^{52}$.

Fourthly, according to the Court, every condition (as well as obligation) should be assessed in the light of the circumstances and objectives of its determination rather than by interpreting separate linguistic phrases - a method, which used in isolation from the context of certain legal relation, may produce conclusions totally inconsistent with that legal relation ${ }^{53}$. Bearing in mind the aim of the concentration condition, which was to prevent OAO Gazprom from using its dominant position and restricting choice for Lithuanian natural gas consumers, the requirement "not to create obstacles", in the Court's opinion, not only obliged the company to refrain from certain actions but established an obligation to take all measures that may be required for the implementation of the concentration condition. Obstacles can be

\footnotetext{
50 Order of the Court, para. 225.

51 Order of the Court, para. 227.

52 Order of the Court, para. 227-228.

53 Order of the Court, para. 229.
} 
created even without taking any action, therefore the requirement "not to create obstacles" had to be understood not only as an inherent passivity of the action, but as a general obligation to act in a way that the concentration condition established by the Council would be implemented. In other words, the concentration condition set in the resolution authorizing concentration, ipso facto comprised both active and passive actions, obliging OAO Gazprom to behave in such a way that the relevant conduct would not prevent Lithuanian gas consumers from purchasing natural gas for their own needs from other suppliers ${ }^{54}$.

This led the Court to argue that OAO Gazprom should have assessed its conduct on a case-by-case basis, taking into account the influence of each behaviour on the concentration condition established by the Competition Council. In this respect, the Court drew attention to the higher standards of care and diligence which apply to entrepreneurs, since the status of an entrepreneur strengthens the requirement to pay attention to circumstances which are important in a contract to acquire assets, and to follow the principles of attention, carefulness, reasonableness and business logic. Consequently, being a non-natural person and not a representative of a small business but having a dominant position on the market, in the Court's view, OAO Gazprom had the necessary means and resources to ascertain the content of the legal obligations applicable to it if they were somehow uncertain or unclear ${ }^{55}$.

In summary, the Court concluded that according to the concentration condition OAO Gazprom had not only to refrain from certain actions, but also had the obligation to take all the measures necessary to fulfil the obligations set in the concentration condition. Such an interpretation could not be considered expanded and was consistent with the circumstances and objectives of the concentration condition, i.e. to ensure the possibility for Lithuanian natural gas consumers to purchase natural gas for their own needs from other suppliers ${ }^{56}$.

\section{Final remarks}

The EU Merger Regulation, under which the Commission is not in a position to impose unilaterally any conditions to an authorisation decision but only on the basis of the parties' commitments, is to be assessed positively: it produces greater clarity of the conditions and obligations that are being imposed by

\footnotetext{
54 Order of the Court, para. 229.

55 Order of the Court, para. 233.

56 Order of the Court, para. 234.
} 
the Commission. An undertaking which proposes specific commitments presumably has the best understanding of what they entail. If conditions and obligations are imposed by the competent authority on the basis of such a proposal, the notifying party is able to understand and implement them better than when the conditions and obligations are designed unilaterally by the authority. Therefore this regulation is likely to reduce the possibility of disputes over the enforcement of remedies. This is particularly important in the case of non-structural ("conduct" or "behavioural") remedies, which are considered as ongoing and are designed to modify or constrain future conduct of merging firms (as was the case with the concentration condition imposed by the Competition Council on OAO Gazprom).

In comparison, the Law on Competition No VIII-1099 does not provide the possibility for undertakings participating in the concentration to propose specific commitments, which would form the basis for conditions or obligations set by the Competition Council. Additionally, the law does not differentiate between remedies by any criteria and therefore, the terms "conditions" and "obligations" are generally regarded as determination of certain forms of behaviour which would help ensure that the concentration would not result in the creation or strengthening of a dominant position. In other words, when it comes to resolving the issue of the legality of a decision of the Competition Council declaring a violation of the remedies of a concentration, it has no legal value if such a remedy is regarded as a condition or an obligation.

The Gazprom case revealed that all this might lead to assumptions for the undertakings to argue the interpretation of the remedies in various aspects. On the other hand, as it has been constituted by the Supreme Administrative Court of Lithuania, higher standards of care and diligence are applied for entrepreneurs and it has all the necessary means and resources to clarify the content of the concentration conditions and obligations applicable to it if they are somehow uncertain or unclear, and/or to challenge its legality in court. Such higher standards of care and diligence give rise to the obligation of an undertaking to be active and show maximum interest in legal nuances relevant to its status and situation, to assess its conduct on a case-by-case basis in view of its possible impact on the conditions and obligations established by the Council, and by all means to challenge them within the time limit, provided in law, and not when a violation of such remedies is being detected.

At the same time it should be noted that in resolution No 1S-4 of 13.01.2005 (i.e. later than concentration condition for OAO Gazprom was imposed) the Competition Council mentioned a possibility for undertakings participating in the concentration to submit commitments, saying that "the Competition Council, after examining the material of the concentration file, may adopt a resolution to authorize the concentration following para. 2 of Article 14 of 
the Lithuanian Competition Act 1999 if the persons submitting the notification have submitted written commitments necessary to prevent the creation or strengthening of a dominant position or substantial restriction of competition, and there are no written objections from the parties concerned"57. This resolution was amended in 2015 to detail general requirements applicable to commitments as well as establishing a procedure for their submission to the Competition Council ${ }^{58}$. Moreover, an obligation to present a non-confidential version of the commitments on the website of the Competition Council was envisaged, making it possible for third parties to become familiar with the content of the commitments and to assess the feasibility and effectiveness of remedies to resolve competition problems ${ }^{59}$.

Judging from the practice of the Competition Council it seems that undertakings participating in concentrations willingly use this new possibility to propose commitments: from its introduction in the resolution No $1 \mathrm{~S}-4$ of 13.01.2005, 10 resolutions allowing concentrations according to the conditions and obligations imposed by the Competition Council were adopted, of which seven contained commitments proposed by the parties ${ }^{60}$. This surely

57 Resolution No 1S-4 of the Competition Council of the Republic of Lithuania, dated from 13.01.2005, which had amended Resolution No. 45 "On approval of the procedure for submission and examination of notification on concentration and of calculation of aggregate turnover", paragraph 12 //TAR, retrieved from: https://e-tar.lt/acc/legalAct.html?documentId=TAR. C3676D989D98\&lang=lt (5.04.2017).

58 Resolution No 1S-82/2015 of the Competition Council of the Republic of Lithuania, dated from 11.08.2015, "On the approval of merger notification and examination procedure", para. 48-50, //TAR, retrieved from: https://www.e-tar.lt/portal/lt/legalAct/ c4004ca040f411e58568ed613eb39a73 (5.04.2017).

59 Resolution No 1S-82/2015, para. 51.

${ }^{60}$ In particular, Resolution No 1S-121 of 27.10 .2005 , retrieved from: http://kt.gov.lt/lt/ dokumentai/del-leidimo-em-rautakirja-oy-em-vykdyti-koncentracija-isigyjant-100-proc-uablietuvos-spaudos-vilniaus-agentura-akciju; Resolution No 1S-190 of 29.12.2007, retrieved from: http://kt.gov.lt/lt/dokumentai/del-leidimo-vykdyti-koncentracija-em-rautakirja-oy-em-isigyjant100-proc-uab-impress-teva-akciju; Resolution 1S-118 of 18.09.2008, retrieved from: http://kt.gov. lt/lt/dokumentai/del-leidimo-maxima-lt-uab-vykdyti-koncentracija-issinuomojant-komercinespaskirties-patalpas-esancias-adresu-naikupes-g-18-klaipedoje-sporto-g-16-marijampolejesavanoriu-pr-375-kaune-pramones-pr-16-kaune-gedvydziu-g-17-vilniuje-vytauto-g-98-senojoturgaus; Resolution No 1S-208 of 7.10.2011, retrieved from: http://kt.gov.lt/lt/dokumentai/ del-leidimo-uab-gintarine-vaistine-vykdyti-koncentracija-isigyjant-100-proc-uab-saulegrazuvaistine-akciju-ir-100-proc-uab-thymus-vaistine-akciju; Resolution No 1S-160/2014 of 9.10.2014, retrieved from: http://kt.gov.lt/lt/dokumentai/del-leidimo-vykdyti-koncentracija-em-powszechnyzakuad-ubezpieczen-spouka-akcyjna-em-isigyjant-iki-100-proc-akcines-bendroves-lietuvosdraudimas-akciju; Resolution No 1S-190/2014 of 5.12.2014, retrieved from: http://kt.gov.lt/ uploads/docs/docs/13701_imp_50488944ddd8e1c0e8474992ac2ec8e5.pdf, Resolution No 1S- 97 (2016) of 18.08.2016, retrieved from: http://kt.gov.lt/uploads/docs/docs/2674_8a6d5756e013fdb a42375c792f65f752.pdf. 
implies a progress in the regulation of concentrations in Lithuania. It has to be stressed that regarding the problematic aspects discussed in this paper, the Lithuanian Competition Act has not been changed since 1999, therefore this modification is based on the Competition Council's self-regulation rather than hard law. However, even this self-regulation does not restrict the Competition Council from issuing conditions unilaterally. Therefore, it seems that the discretion of the Competition Council has not changed allowing it to formulate concentration conditions and obligations in a manner chosen by this institution, potentially fully separating them from commitments proposed by the undertakings. Thus, in terms of assumptions for undertakings to argue for interpretation and clarity of those remedies in court, the lessons of the Gazprom case remain to be learned for the future.

\section{Literature}

Banevičienè, A. (2005). Koncentracijos sampratos skirtumai remiantis Lietuvos ir Europos bendrijos teisès normomis, reguliuojančiomis koncentracijas. Jurisprudencija 72(64).

Banevičienè, A. (2009). Nehorizontaliu koncentraciju teisinis reguliavimas pagal Europos Bendrijos ir Lietuvos Respublikos konkurencijos teise, doctoral dissertation, Mykolas Romeris University Vilnius. Retrieved from: http://vddb.library.lt/fedora/get/LT-eLABa0001:E.02 2009 D_20091202_092341-45797/DS.005.0.01.ETD (5.04.2017).

Cook, C.J., Kerse, C.S. (2000). E. C. Merger Control. London: Sweet\&Maxwell.

Cseres, K.J. (2005). Competition Law and Consumer Protection. Hague: Kluwer Law International.

Hellstrom, P., Maier-Rigaud, F. and Wenzel Bulst, F. (2009). Remedies in European Antitrust Law, Antitrust Law Journal 1.

Hoeg, D. (2014). European Merger Remedies: Law and Policy. Oxford: Hart Publishing.

Layne - Farrar, A., Geradin, D. and Petit, N. (2012). EU competition law and economics, Oxford University Press: Oxford.

Maier-Rigaud, F.P. and Frank, P. (2016). Behavioural versus Structural Remedies in EU Competition Law [in:] P. Lowe, M. Marquis and G. Monti (eds.). European Competition Law Annual 2013, Effective and Legitimate Enforcement of Competition Law. Hart Publishing, 207-224.

Niels, G., Jenkins, H. and Kavanagh, J. (2011). Economics for Competition Lawyers, Oxford: Oxford University Press.

van Bael, I. (2001). Due Process in EU Competition Proceedings. Kluwer Law International, Alphen aan den Rijn. 